\title{
Attitude of Student Nurses and Midwives Towards Research: Study of Schools of Nursing and Midwifery Mkar, Gboko Benue State, North Central Nigeria
}

\author{
Emmanuel O. Chukwu ${ }^{1}$, Ifeoma S. Nwakanma², Terna M. Fiase ${ }^{3}$, Esther M. \\ Iornengen ${ }^{4}$ \\ ${ }^{1,2,3}$ School Of Nursing Mkar, Gboko. ${ }^{4}$ School Of Midwifery, Mkar, Gboko, Nigeria \\ Email:-emmanwaguy42@yahoo.com
}

\begin{abstract}
The research is a cross-sectional descriptive survey conducted at school of Nursing and Midwifery Mkar, Gboko Benue State, North Central Nigeria to study the attitude of student nurses and midwives towards research study. The specific objectives of the study were: to assess students' knowledge on importance of research in client care, to determine the attitude of students towards research study, to identify reasons for frequent repetition of some research topics among students and to find out barriers to effective research study among students. The study will help the students to have positive look towards research thereby helping them to develop a positive attitude towards research in order to maintain evidence base practice in Nursing. Simple probability sampling technique was used in selection of samples used for the study. Data were collected from the respondents through self-structured and validated questionnaire. Data obtained were presented and analyzed using frequency distribution table. Based on the findings, all the students are aware of importance of research in client care but attitudes towards research is unfavorable as most of the students believe that research in general is difficult and time consuming, hence their cold attitude towards research. This research also find out that one of the reasons for frequent repetition of some research topics is because of excessive academic workload which leave them with little time for research work. Based on the findings, the following recommendations were made: that more time should be allocated for research studies in nursing and midwifery schools, thus helping the students develop interest in research; the students must also change their attitude towards research in order to learn and practice evidence based nursing.
\end{abstract}

Keywords: Attitude, Student Nurses and Midwives, Research, Study

\section{Introduction}

In the fast moving world, research has important intellectual equipment for the human beings to change their lifestyles according to needs and necessities of the society. Research opens new frontier in all fields like medicine, agriculture, business, education and also in nursing (Alba, 2009). Nurse education and practice places emphasis upon the use of evidence from research in order to rationalize nursing intervention (Polit and Beck, 2010).

The focus of this study is on the attitudes of students nurses and midwives towards research study in schools of nursing and midwifery Mkar, Gboko local Government Area of Benue state.

\section{Operational definition of terms}

1. Attitude: The way that one behaves towards something that show how the person think and feel about that thing.

2. Student nurses and midwives: persons who are undergoing training to become a nurse/midwife at a nursing and midwifery school respectively.

3. Research: A process which has to be undertaken according to scientific rules and consist of a sequence of steps which include mental activities, designed to increase the sum of what is known about a certain phenomenon. 
4. Study: The activity of learning or gaining knowledge, either from books or by examining things in the world, as well as writing a project.

\section{Methodology}

Research Design: This is a cross-sectional descriptive survey design to study the attitude of student nurses and midwives towards research study in school of Nursing and Midwifery Mkar, Gboko, Benue State.

Research Setting: The study was conducted in schools of nursing and midwifery Mkar, Gboko LGA of Benue State. The school is located along Gboko MkarKatsina/Ala road. It has a population of about 270 students in Nursing arm and about 217 students in Midwifery arm.

Target Population: The target population consists of all the final-year students including those awaiting their final qualifying Nursing and Midwifery Council examination result in both schools of Nursing and Midwifery Mkar Gboko LGA of Benue state. The study population numbered 252 students.

Sample/Sampling Technique: In determining sample size, Nwanna (1981) stated that if a population is a few hundreds, $40 \%$ of the population could be used, If few thousand 10\% could be used. If many hundreds, $20 \%$ sample could be used, if few thousand $10 \%$ could be used and if a several thousand $5 \%$ sample could be used. In line with the above assertion $40 \%$ of the population was used thus percentage to be used $=40 \% \ldots{ }^{40} / 100 \mathrm{x}^{252} / 1=100$

Thus the sample size is 100 students from both schools. A simple random sampling technique was used in selecting 100 students out of 252 students. It was done using ballot method without replacement. Here "yes" and "no" were written on papers of equal size and the papers were folded, then every member of the sample unit was given equal opportunity to pick from the papers. Only those who picked the ones with "yes" were eligible to participate in the study, whereas those that picked the ones with "no" were not eligible to participate in the study.

Description of Data Collection Instrument: A self-designed, structured questionnaire was used for data collection. The questionnaire was designed in lined with the objectives of the study. It has sections, with each section eliciting information on the research question.

The questionnaire has first introductory part, where the researcher introduces herself to her respondents, instructing them on what is expected of them and how to answer the questions. Section "A" of the questionnaire has to do with the sociodemographic data of the respondents. Section "B" was designed to initiate information on research questions number one and correspondingly section " $C$ " " $D$ " and "E" taking care of research questions 2,3 , and 4 . The questionnaire was given to other researchers for face validity, criticism and corrections of the instrument after which it was pre-tested on similar target population who were not from school of Nursing and Midwifery Mkar. The researcher conducted the pre-test of the questionnaire using 10 questionnaire on students of School of Nursing Makurdi, Benue State.

Method of Data Collection: A hundred (100) questionnaires were distributed by the researchers to all the students of nursing and midwifery who were selected from the population using simple random sampling method, making use of ballot paper method as described under sample and sampling techniques above. The questionnaires were given to the respondents in the class and respondents who could not fill theirs immediately took it home and were allowed to return it to the researchers in school on the second day.

Method of data Analysis: The data obtained from the distributed questionnaires was analyzed using frequency distribution table which show responses of the respondents and analyzed in percentages. The data collected were also presented in 
pie charts and bar charts.

Ethical Consideration: The researchers sought for permission from the principals of the schools who gave the approval for the study to be conducted in their respective schools. Privacy and confidentiality was maintained in getting information from the respondents by demanding for neither their names nor address. The researcher ensured that the subjects understand the nature and purpose of the research, and how they will benefit from it. Their consent was obtained before they were included in the study.

\section{Results}

Table 1. Socio-demographic data

\begin{tabular}{|l|l|l|}
\hline Age & Response & Percentage \\
\hline $19-24$ years & 45 & 45 \\
\hline 25-30years & 42 & 42 \\
\hline 31 years and above & 13 & 13 \\
\hline Total & $\mathbf{1 0 0}$ & $\mathbf{1 0 0}$ \\
\hline Sex & & \\
\hline Male & 11 & 11 \\
\hline Female & 89 & 89 \\
\hline Total & $\mathbf{1 0 0}$ & $\mathbf{1 0 0}$ \\
\hline Marital Status & & \\
\hline Single & 72 & 72 \\
\hline Married & 28 & 28 \\
\hline Widow & - & - \\
\hline Divorcee & - & - \\
\hline Total & $\mathbf{1 0 0}$ & $\mathbf{1 0 0}$ \\
\hline Religion & & \\
\hline Christianity & 100 & 100 \\
\hline Islam & - & - \\
\hline Other & - & - \\
\hline Total & $\mathbf{1 0 0}$ & $\mathbf{1 0 0}$ \\
\hline
\end{tabular}

Age status

The age of respondents shows that out of 100 respondents, $45 \%$ fall within the age range of $19-24 y e a r s, 42 \%$ fall within the range of 25 -30years and $13 \%$ fall within 31 years and above. This indicates that both the young adult and the aged are represented in this research study.

\section{Sex status}

Sex Status of respondents shows that out of 100 respondents, $89 \%$ are female and $11 \%$ are male. This shows that both men and women were used for this study.

\section{Marital Status}

The marital status of the respondent's shows that out of 100 respondents, $72 \%$ are single, $28 \%$ are married and non is widow and divorce this is to say that all were considered.

\section{Religious Status}

Religious status shows that $100 \%$ of respondents are Christians. This is possible due to the school is a mission own. 
South American Journal of Nursing

Special Edition 2016

\section{Are Students aware of importance of research in client care.}

The data answering this research question is presented in table two, three, figure one and two below.

Table 2. Awareness of Importance of research in client care

\begin{tabular}{|l|l|l|l|}
\hline Item & Variables & Frequency & Percentage (\%) \\
\hline $\begin{array}{l}\text { Is research } \\
\text { important }\end{array}$ & Yes & 100 & 100 \\
\hline In client care & No & - & - \\
\hline & Total & $\mathbf{1 0 0}$ & $\mathbf{1 0 0}$ \\
\hline
\end{tabular}

The table two above shows that $100 \%$ of the respondents said yes that research is important in client care. This shows that all the respondents are aware of importance of research in nursing.

Table 3. Knowledge of the importance of research

\begin{tabular}{|c|c|c|c|}
\hline Item & Variables & Frequency & Percentage (\%) \\
\hline \multirow{4}{*}{$\begin{array}{l}\text { In what way is } \\
\text { research } \\
\text { Important in care of } \\
\text { clients }\end{array}$} & $\begin{array}{l}\text { Promoting health } \\
\text { lifestyles }\end{array}$ & 40 & 40 \\
\hline & $\begin{array}{l}\text { Aid patients } \\
\text { recovery }\end{array}$ & 30 & 30 \\
\hline & $\begin{array}{l}\text { Reduce number of } \\
\text { diseases in the } \\
\text { community }\end{array}$ & 30 & 30 \\
\hline & Total & 100 & 100 \\
\hline
\end{tabular}

Table three above which answers the question, in what way is research important in client care indicates that $40 \%$ of the respondents said it helps in promoting healthy lifestyles, 30\% said it aid patient's recovery and 30\% said reduces number of disease in the community.

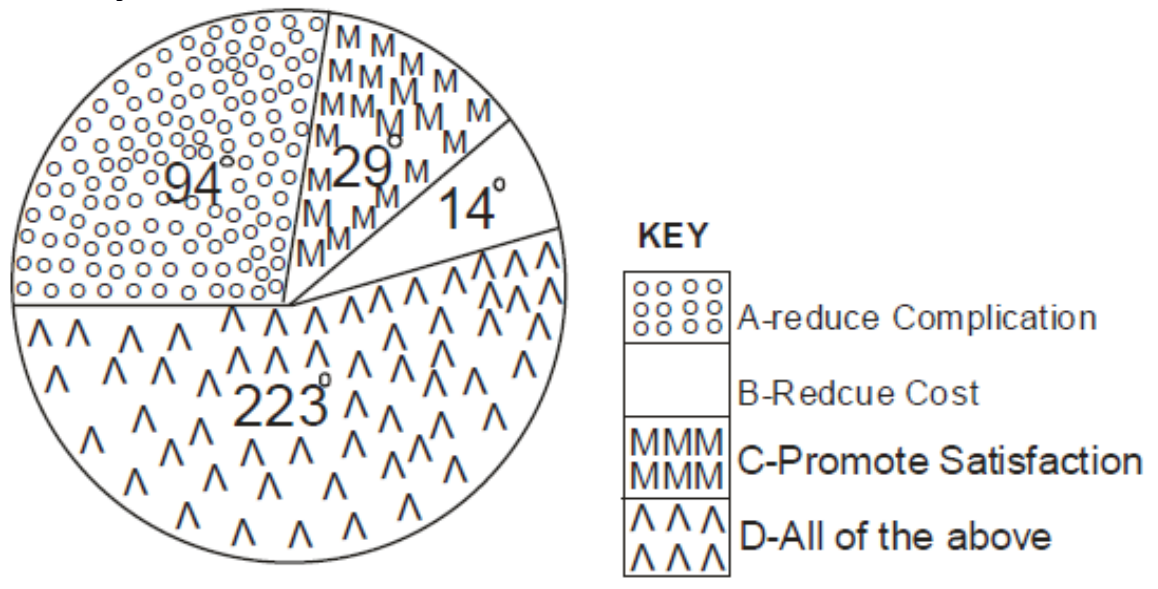

Figure 1. Information from research ensured what?

Figure one above which answers the question information from research ensures what shows that 2230 represented by $62 \%$ said it ensures all of the above, 940 represented by $26 \%$ said it reduce complications, 29o represented by $8 \%$ said it promote satisfaction and $14 \mathrm{o}$ represented by $4 \%$ said it reduces cost of health care. 


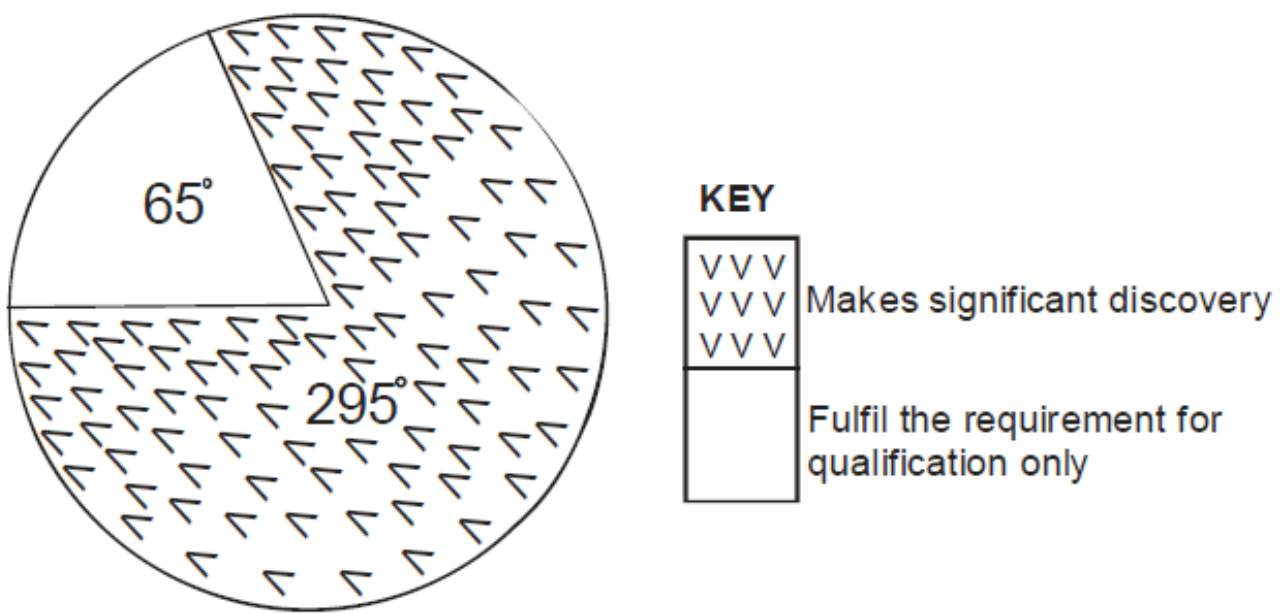

Figure 2. The goal of research project of respondents

The Figure Two above which reveal the goals of respondents research project indicates 2950 represented by $82 \%$ said it is to makes a significant discovery while 65 o represented by $18 \%$ said to fulfill the requirement for qualification only

What are the attitudes of students towards research study?

The data answering this research question is presented in table four, table five, figure three and figure four below

Table 4. Students attitudes towards research study I

\begin{tabular}{|l|l|l|l|}
\hline Item & Variables & Frequency & Percentage (\%) \\
\hline $\begin{array}{l}\text { Research in general } \\
\text { Is difficult and } \\
\text { Many students do } \\
\text { Not like researching }\end{array}$ & Strongly agreed & 31 & 31 \\
\cline { 2 - 4 } & Agreed & 55 & 55 \\
\cline { 2 - 5 } & Disagreed & 4 & 4 \\
\cline { 2 - 5 } & Strongly Disagreed & 10 & 10 \\
\hline & & & $\mathbf{1 0 0}$ \\
\hline
\end{tabular}

The table four above shows that $31 \%$ of the respondents strongly agreed that research in general is difficult and many students do not like researching, 55\% agreed, $4 \%$ disagreed and $10 \%$ strongly disagreed. This indicates that majority of respondents have negative attitude toward research study. 
South American Journal of Nursing

Special Edition 2016

Table 5. Students Attitudes towards research study II

\begin{tabular}{|l|l|l|l|}
\hline Item & Variables & Frequency & Percentage (\%) \\
\hline $\begin{array}{l}\text { Students lack } \\
\text { confidence in doing } \\
\text { their research }\end{array}$ & Strongly agreed & 18 & 18 \\
& & & \\
\cline { 2 - 4 } & Agreed & 56 & 56 \\
\cline { 2 - 4 } & Disagreed & 26 & 26 \\
\cline { 2 - 4 } & Strongly Disagreed & - & - \\
\hline & Total & $\mathbf{1 0 0}$ & $\mathbf{1 0 0}$ \\
\hline
\end{tabular}

Table five above shows that $18 \%$ of the respondents strongly agreed, $56 \%$ agreed, and $26 \%$ disagreed that students lack confidence in carrying out their research. This indicates that majority of students lack confidence in doing their research. This also indicate unfavorable attitude towards research study.

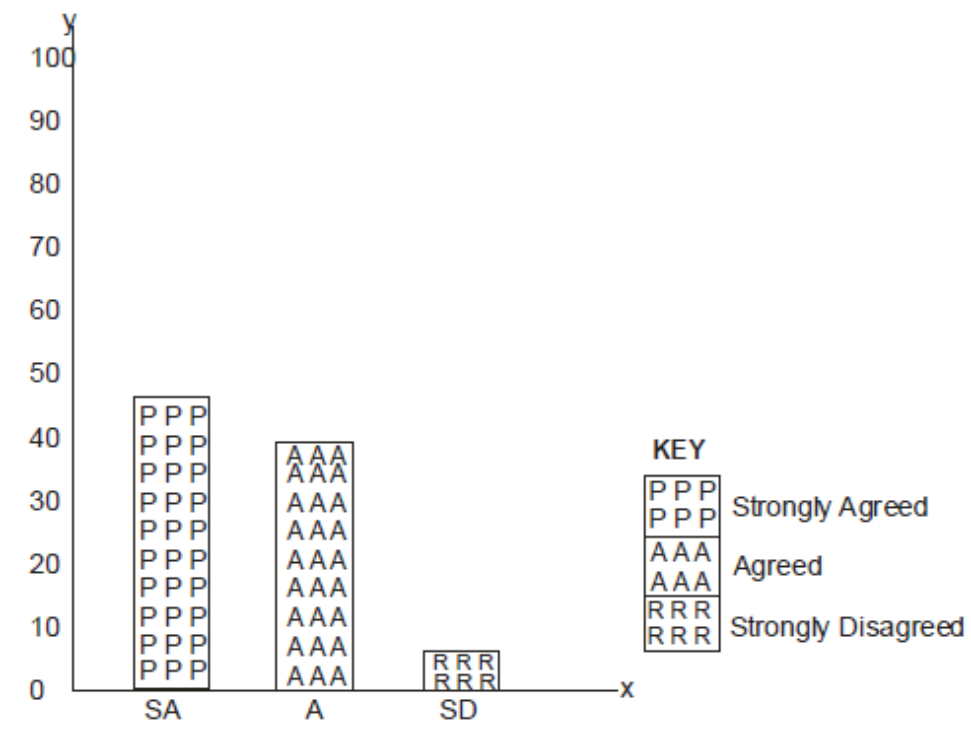

Figure 3. Many Students get frustrated when corrected several times by supervisors

The figure above indicates that $58 \%$ of respondents strongly agreed that many students get frustrated when corrected several times by supervisors, 39\% agreed and $3 \%$ strongly disagreed while $0 \%$ disagreed. This indicate negative attitude towards research study.

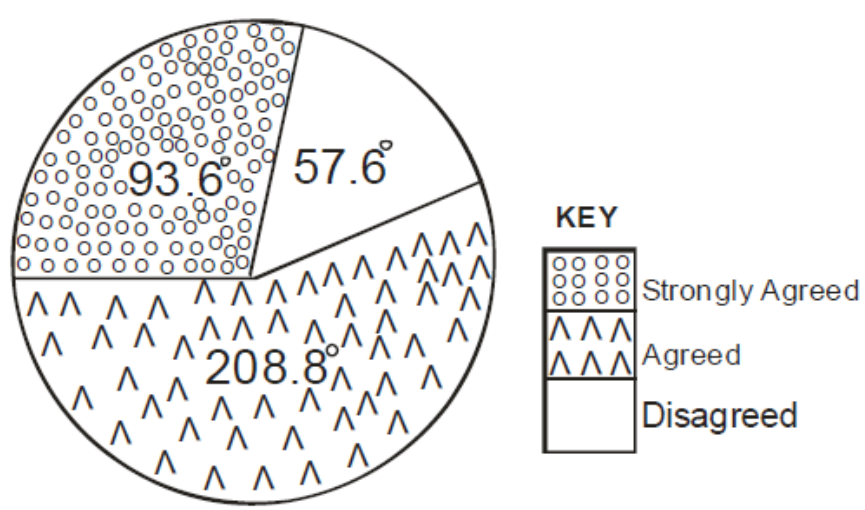

Figure 4. Many students do not understand research process

This pie chart above indicates that 93.60 represented by $26 \%$ strongly agreed that many students do not understand research process, 2080 represented by $58 \%$ agreed and 57.60 represented by $16 \%$ disagreed. And this indicates unfavorable attitudes towards research. 


\section{Reasons for frequent repetition of some particular research topics among students?}

The data answering the research question is presented in table VI, VII and figure Five respectively

Table 6. Frequent repetition of topics

\begin{tabular}{|l|l|l|l|}
\hline $\begin{array}{l}\text { Has your research } \\
\text { topic been } \\
\text { researched on } \\
\text { before by other } \\
\text { senior students }\end{array}$ & Yes & 70 & 70 \\
\hline & No & 30 & 30 \\
\hline & Total & $\mathbf{1 0 0}$ & $\mathbf{1 0 0}$ \\
\hline
\end{tabular}

The table above shows that $70 \%$ of the respondent's research topics have been researched on before by other senior students while 30\% have not been researched. This indicates increase repetition of research topics among students.

Table 7. Frequency of repletion

\begin{tabular}{|l|l|l|l|}
\hline Item & Variables & Frequency & Percentage (\%) \\
\hline $\begin{array}{l}\text { How many times has } \\
\text { your topic been } \\
\text { researched on by } \\
\text { other senior student }\end{array}$ & Nil & 30 & 30 \\
\hline Once & 3 & 3 & \\
\hline Twice & 48 & 48 & \\
\hline Three & 14 & 14 & \\
\hline Four & 5 & 5 & $\mathbf{1 0 0}$ \\
\hline & Total & $\mathbf{1 0 0}$ & \\
\hline
\end{tabular}

The table VII above shows that $30 \%$ of the topics have not been researched on, $3 \%$ have been researched on once, $48 \%$ have been researched on twice, $14 \%$ have been researched on three times and 5\% have been researched on four times. This indicates increase rate of repetition of topics among students.
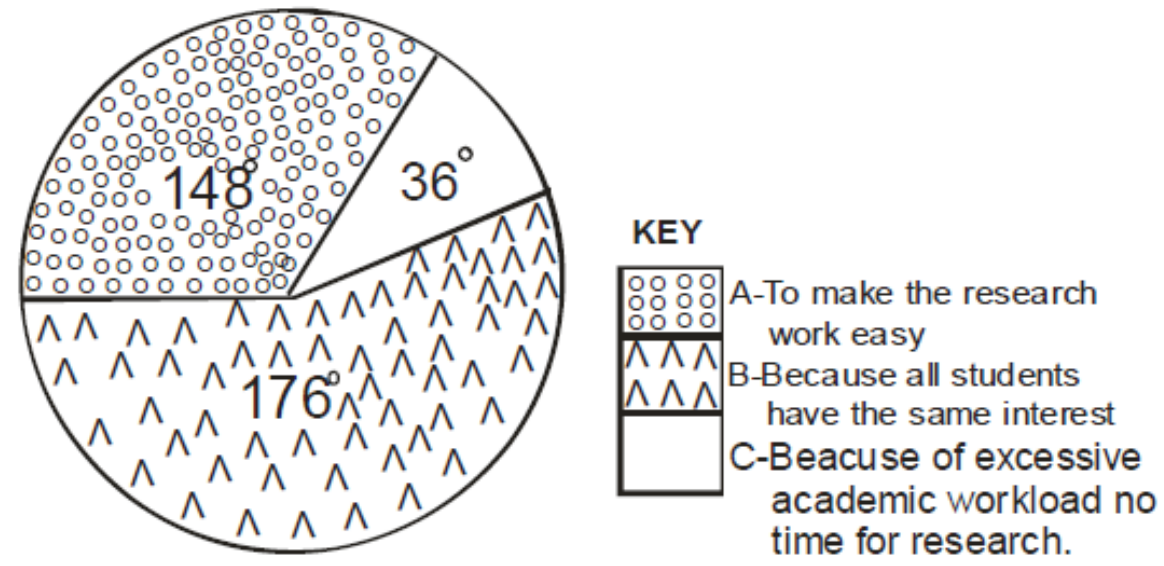

Figure 5. Reasons for frequent repetition of topics

The pie chart above indicates that 148 o represented by $41 \%$ said it's to make the research work easy, 360 represented by $10 \%$ said it's because all students have the same interest and 1760 represented by $49 \%$ said it's because of excessive academic

\section{Barriers to effective research study among students}

The data answering the research question is presented in table VIII and IX below. 
South American Journal of Nursing

Special Edition 2016

Table 8. Barriers to effective research study

\begin{tabular}{|l|l|l|l|}
\hline Item & Variables & Frequency & Percentage (\%) \\
\hline $\begin{array}{l}\text { The common barrier } \\
\text { to effective research } \\
\text { are }\end{array}$ & $\begin{array}{l}\text { Inadequate } \\
\text { statistical data }\end{array}$ & 17 & 17 \\
\hline & $\begin{array}{l}\text { Time } \\
\text { factors(inadequate) }\end{array}$ & 62 & 62 \\
\hline & $\begin{array}{l}\text { Inadequate lectures } \\
\text { on research }\end{array}$ & 5 & 5 \\
\hline & $\begin{array}{l}\text { Insufficient prior } \\
\text { research }\end{array}$ & 16 & 16 \\
\hline & Total & $\mathbf{1 0 0}$ & $\mathbf{1 0 0}$ \\
\hline
\end{tabular}

The table VIII above shows that $17 \%$ of respondents said that the common barriers to effective research among student is adequate statistical data, $62 \%$ said it's time factors, $5 \%$ said it's inadequate lectures on research and $16 \%$ said it's insufficient prior research. This means that time allow for research is short and then hinders effective research among students.

Table 9. Staff (Lecturers) attitude towards research

\begin{tabular}{|l|l|l|l|}
\hline $\begin{array}{l}\text { Research often } \\
\text { taught seem not } \\
\text { actually inspiring } \\
\text { students passion for } \\
\text { research }\end{array}$ & Yes & 30 & 30 \\
\hline & No & 70 & 70 \\
\hline & Total & $\mathbf{1 0 0}$ & $\mathbf{1 0 0}$ \\
\hline
\end{tabular}

The table IX above indicates that $30 \%$ of the respondents answer yes to the question while $70 \%$ of respondents answers no to the question. This means that staff (lectures) does justice to the course, research. Student should add more effort in learning research.

\section{Discussion of findings}

According to Royal College of Nursing (2009) Research is an indispensable part of a modern, effective and essential to the provision of effective and safe and social care. One of the important objectives of research in nursing and midwifery schools is to create awareness and understanding of important of research in the class-room, thus action research become a part of the syllabus where in the students are expected to prepare action plans and implement the same during their final year sessions in nursing school. This in turn is strengthened in post graduate programme in university (Ofoegbu, 2009).

The main aim of research in nursing course is to provide capabilities of serving community in general and developing research attitude and skill among the students in specific. Those students in future have to promote interest towards research in nursing profession when they take up their jobs as nurse practitioners or educators.

Abba (2006) defined nursing research as an investigative process of finding reliable solution to problems of nursing through a planned and systematic selection of data relating to the nursing problems. A broad definition of research was given by (Martyn, 2008) in the broadest sense of the word, the definition of research includes any gathering of data, information and facts for the advancement of knowledge. An attitude may be defined as a predisposition to respond in a favorable or unfavorable Manner with respect to a given object (Oskamp and Schults, 2005). 


\section{Objective one : to assess students' knowledge on importance of research in client care}

Analysis of table two clearly revealed that $100 \%$ of students are aware of importance of research in client care. This finding is supported by that of Khalid et al (2014) whose work revealed that $97.1 \%$ of medical students studied agreed that research is important in medical field. According to Royal College of Nursing (2009), Research is an indispensable part of a modern, effective and essential to the provision of evidence based care which modern nursing entails.

Analysis of table III which answers the question on: in what way is research important in care of client reveals that $40 \%$ of respondents said it help to promote healthy lifestyles and prevent onset of preventable diseases, 30\% said it help in developing advancement that aid patient in recovery, and $30 \%$ said it help in developing standards that help to reduce the number of diseases in the community. This shows that all the students are very much aware of the importance of research in nursing.

Analysis of figure one which shows what students said that information from research ensures (940 represented by 26\%) said it ensure reduction of complication, ( 290 represented by 8\%) said it promote satisfaction, (140 represented by 4\%) said it reduces cost of health care and (2230 represented by 62\%) said it ensures all of the above. According to Marita (2013) Nursing profession has more recently provided major leadership for improving health care through application of research findings in practice.

Analysis of figure two which answers what is the goal of your research project reveals that (2950 represented by $82 \%$ ) said to make significant discovery while (650 represented by $18 \%$ ) said to fulfill the requirement for qualification only. This shows that while majority of students carryout researches for new discoveries, some students often undertake research for the sake of pre-requisite for qualification only and not with a goal to make a significant discovery. This finding is in agreement with Basavanthappa (2007), that one of the major goal of research is to make significant discovery that will aid in solving problems of man.

\section{Objective two: to determine the attitude of students towards research study}

It was discovered in table four which shows that $31 \%$ of respondents strongly agreed that research in general is difficult and many students do not like researching, $55 \%$ agreed, $4 \%$ disagreed and $10 \%$ strongly disagreed. This is in line with the study of Newell and Cunlife (2010) which reveal that 54\% of 119 students belief research in general is difficult, $42 \%$ belief it is interesting while $75 \%$ consider it necessary.

Analysis of table five reveals that $18 \%$ of the respondents strongly agreed that students lack confidence in doing their research, 56\% agreed and 26\% disagreed. This indicates unfavorable attitude towards research study. This work differs with that of Sridevi (2010), whose findings revealed that majority (92\%) of education students studied have favourable attitude towards research. In same vain, findings by Sadia et al (2014) revealed that majority of post graduate students studied have positive attitude towards research. The observed disparities could be due to differences in motivation by the school and lectures on students towards research. The difference in the findings could be in line with the finding of Adamsen et al (2006) whose finding reveal that earlier introduction of research method course to students had positive effects on the nurses' research activity and increases their commitment to research compared to group that were not early introduced to research methods course.

Analysis of figure four indicates that (208.80 represented by 58\% ) strongly agreed that many students do not understand research process (93.6 represented by $26 \%$ agreed) while (57.60 represented by 16\%) disagreed and this also indicates 
South American Journal of Nursing

Special Edition 2016

inattentiveness in the class and unfavorable attitude.

Objective three: to identify reasons for frequent repetition of some particular research topic among students.

Table six shows that $70 \%$ of the students research topics have been researched on before by other senior students, while only $30 \%$ of the topics have not been researched on before by other senior students. This means that student repeat research topic.

Table seven shows the rate at which the topics have been repeated. $30 \%$ of the topics have not been researched on before by senior students, while $3 \%$ have been research on once, $48 \%$ have been researched on twice, $124 \%$ have been researched on three times and 5\% have been researched on four times. This indicate increase rate of repetition of topics among students and this agrees with Orjih (2009) that students are research phobic and that research has then become imitative and repetitive.

Analysis of figure five reveals the reasons for repetition of topics among student (148o represented by $41 \%$ ) said it is to make the research work easy, (36o represented by $10 \%$ ) said it was because all students have the same interest and (176o represented by $49 \%$ ) said it was because of excessive academic workload thus not having enough time for research work. This finding is in agreement with Lilian (2012) that when students possess a positive attitude towards research methods and statistics, they tend to put more effort into studying the subject.

\section{Objective four: to find out barrier to effective research study among students.}

Analysis of table eight reveals that $17 \%$ of respondents said that the common barrier to effective research is inadequate statistical data, $62 \%$ said it was time factor, $5 \%$ said it was inadequate lectures on research and $16 \%$ said it was insufficient prior research. This finding is in agreement with Khalid (2014) which result showed obstacle that prevented students from conducting research as:84.7\% lack of professional supervisors, $88.8 \%$ lack of training courses, $72.3 \%$ lack of adequate time and 54.1\% lack of funding. Bosa (2012), stated that evidence based practice depends on a number of factors including attitude towards and knowledge of research, the availability and access to relevant research, adequate resources and supervisors support. It is important that students be given adequate time to research, making them actively involved in order to ensure evidence base practice in nursing.

\section{Limitation of the study}

The constraints faced by the researchers were the following:

1. Insufficient prior research: Research is a cumulative process, present research builds on the prior research, however there are relatively few investigations who have examined the attitude of students nurse and midwives towards research study and this made literature review difficult for the researcher.

\section{Conclusion}

Based on the findings from the study and statistical analysis, the following conclusions were reached; awareness of importance of research in client care is high, as all the students testified that but the attitudes towards research is unfavorable as most of the students belief research in general is difficult and time consuming, so they dislike researching.

Little thing that make a big difference is attitude. Students should endeavor to change their unfavorable attitudes towards research and they will find research very interesting. Students should also note that discovering a fact or thing on your own or learning it from literature reviewed improves ones competence. 


\section{Recommendations}

The researcher after the research findings came up with the following recommendations.

1. Nursing and Midwifery Council of Nigeria should look into the curriculum of nurses and if possible introduce research right from 200level for students of school of nursing and midwifery as against the current practice in which teaching of research starts only in 300 level( final year) which normally clash with their other preparation for final qualifying exams.

\section{Suggestion for further studies}

Following the findings of the study the researcher hereby suggest the following for further studies.

1. Knowledge and utilization of research findings among nurses.

2. Knowledge and impact of research on nursing students.

\section{References}

[1]. Abba K. (2006) Research Methods in Nursing. Second Edition.H.M. Great \& Associates, Maiduguri.

[2]. Adamsen 1., Larsen K. and Bjerregaard L. (2006), Moving Forward as Nurses Through Research. Retrieved 6th April 2014 from www.vbn.aau.dk./../export.html

[3]. Alba G. (2009), Identifying the Barriers and Opportunity for the Implementation of Research Retrieved 16th April 2014 uwspace.uwter100.ca/handle/10012/4549.

[4]. Basavanthappa, B. T. (2009) Nursing Research. Second Edition. Jaypee Brothers Medical Publishers (p) Ltd, New Delhi.

[5]. Bosa J.C. (2012) Introduction to Research Methodology in Health Education. Tina Chin Enterprises, Ikeja Lagos Nigeria.

[6]. Khalid, M. A., Noura, A. M., Dara, S. A., Nermeen, A., and Adwa S.A. (2014) Perceptions, Attitudes and Practices towards Research Among Senior Medical Students. Saudi Pharmaceutical Journal, Vol. 22, Issue 2 P. 113-117

[7]. Lilian, K. Y. (2012) A Study of the Attitudes, Self-efficacy, Effort and Academic Achievement of City University Students Towards Research Methods and Statistics. SS Student E-Journal Vol.1, p.154183.

[8]. Martyn S. (2008) Definition of Research. Retrieved 3rd April 2014 from www.explorable.com/definition of - research.

[9]. Marita G. T (2013) Evidence for Evidence-Based Practice Implementation. Free press New York.

[10]. Newell D. and Cunlife C. (2010), Attitude of Chiropractic Students Towards Research. Retrieved 21st March 2014 from www.ir.dut.ac.za/handle/0321/500.

[11]. Nwanna, O. C (1981) Introduction to Educational Research. Heinemann Educational Books Plc, Ibadan.

[12]. Ofoegbu V. I (2009) Concise Text on Research Methods and Elementary Statistics. 2nd Edition. Ocean Press, New Market Road, Nkpor

[13]. Orjih, J. (2009) Business Research Methodology. Meteson Publicity Company, Maryland, Enugu.

[14]. Oskamp S. and Schultz P. (2005), Attitude and Opinions. 3rd Edition. Mah.wah, Nj.

[15]. Polit, D. F and Beck, C. T (2010) Essentials of Nursing Research, Appraising Evidence for Nursing Practice. Seventh Edition. Wolters Kluwer/ Lippincott Williams \& Wilkins.

[16]. Royal College of Nursing (2009), Research Ethics; RCN Guidance for Nurses. Retrieved 24th March from www.rcn.org.uk/../003/38/pdf.

[17]. Sadia, S., Aishah, S., Muhammad, A., and Rafaqat, A. B. (2014) Postgraduate Students'Attitudes Towards Research. Bulletin of Education and Research, Vol. 36 No.1pp. 111-122.

[18]. Sridevi K.V (2010), Research in Health Education: a Review of the Literature Journal of Nursing Research vol 14 No11 pg 67-111. Retrieved from www.aiaer.net/ejournal/vol20108/14.htm 